\title{
LXXXIV. An account of various substances found in the guano deposits and in their vicinity
}

\section{E.F. Teschemacher Esq.}

To cite this article: E.F. Teschemacher Esq. (1846) LXXXIV. An account of various substances found in the guano deposits and in their vicinity , Philosophical Magazine Series 3, 28:190, 546-550, DOI: $10.1080 / 14786444608645468$

To link to this article: http://dx.doi.org/10.1080/14786444608645468

曲 Published online: 30 Apr 2009.

Submit your article to this journal $\square$

Џ Article views: 3

Q View related articles ๘ 
and of various scientific men, that the prolonged passage of the electricity by metallic wires alters essentially their tenacity. It seemed to me very probable that the elasticity of wires subjected for some time to the intermittence of currents which renders them sonorous, must be altered in a permanent manner.

Since the experiments just mentioned were made, $M$. Wertheim has published * a very interesting note, in which he describes a process of observation analogous to mine, although less delicate, and indicates the causes to which he attributes the sounds produced. Although I agree with him on most points, I differ from him both as to what relates to the attraction exerted from the two sides of the centre of the helix, an attraction which he does not mention, and in the explanation of the case in which the wire is directly traversed by the discontinuous current. The skilful experimentalist whom I have just named attributes the sound produced to the heat engendered by the current. Nevertheless my wire indicated no perceptible heat. It results from the experiments of M. de la Rive and my own, that the sonorous state continues with more than 600 interruptions a second. How shall we admit that the elevation of temperature and the diminution of elasticity which accompany it can disappear in $\frac{1}{60} \overline{0}$ th of a second? The current of a pile of eleven pairs certainly does not alter the thermical state of a bar of a centimetre square in section, as I have directly established $t:$ nevertheless, if it is discontinuous, it renders it sonorous. I may add, finally, that this heating does not take place when the reel is employed, as any one may convince himself by placing a bismuth and iron pair in its hollow, connected with a very delicate rheometer. Nevertheless the sonorous property may be the same as with the wire directly subjected to the current.

Lausanne, March 16, 1846.

LXXXIV. An Account of various Sulstances found in the Guano Deposits and in their Vicinity. By E. F. TescheMACHER, Esq. $\ddagger$

$\mathrm{R}$ EPORTS having been circulated that large quantities of $\mathrm{R}$ saltpetre (nitrate of potash and nitrate of soda) were to be found of a very good quality in the neighbourhood of the guano deposits on the coast of Africa, numerous vessels were

- Compter Rendus, Feb. 23, 1846.

† Phil. Mag., Oct. 1843; Archives de l' Electricité, vol. ii. page 601.

$\ddagger$ Communicated by the Chemical Society; having been read December 1,1845 . 
found in the Guano Deposits and in their Vicinity. 547

despatched both from London and Liverpool in search of those valuable substances, particularly as it was considered they might be obtained upon the same terms as Ichaboe guano, namely, for nothing but the labour and expense of fetching. No favourable accounts however have as yet been received as to the success of these undertakings. The evidence of such deposits existing there at all was very unsatisfactory; the circumstance much relied upon was the existence of large beds of nitrate of soda in the neighbourhood of the coast of South America, and large deposits of guano similar in many respects to the deposits of guano on the African const : there was certainly an abundance of animal matter and ammoniacal salts to furnish the nitric acid, and a temperature high enough to effect the decomposition, but the source from whence the alkaline bases of potash and soda were to be derived was not very evident. The principal source of saltpetre in the East Indies is from numerous districts of nitrous earth found on the surface of the soil, which being compounds of lime and magnesia with nitric acid, they are dissolved out, and the saltpetre subsequently formed by the decomposition of these nitrous compounds by potash salts. The nitrate of soda saltpetre beds in the Province of Tarapaca near Iquiqua on the coast of South America, are the only instances known of the occurrence of saltpetre ready-formed in extensive beds, but even this deposit contains the salt in a state of great impurity.

These explorations, however, on the African coast have brought to light various other substances which have been found there, the details of which are more particularly the object of this communication.

The substances which I shall now describe are found in the guano beds, or in their vicinity, either in a crystalline state, or in distinct masses. The first substance is a crystalline salt, perfectly transparent, with a cleavage and brilliant faces in one direction only; it gives a yellow precipitate with nitrate of silver; gives off ammonia upon application of caustic potash, and when heated to redness loses about 50 per cent. of water and ammonia ; I consider it therefore to be phosphate of ammonia. The portion of salt I examined consisted only of a few grains, and was consequently too small a quantity to analyse with exactness.

The next substance was also a crystalline salt a little mixed with guano in its cavities; it possessed a cleavage with brilliant planes in two directions: upon examination with the reflecting goniometer, it gave $112^{\circ}$ as the measurement of the angle formed by the meeting of the adjacent planes. Upon analysis I found it to consist of - 


\section{0 parts of Ammonia. \\ $55.50 \quad \ldots \quad$ Carbonic acid.$$
\frac{23.50}{100 \cdot 00} \quad \cdots \quad \text { Water. }
$$

being nearly equivalent to 1 atom of ammonia, 2 atoms of carbonic acid, and 2 atoms of water.

$$
\text { Formula } \mathrm{NH}_{5}+2 \mathrm{CO}_{2}+2 \mathrm{HO} \text {, }
$$

and is consequently a bicarbonate of ammonia.

The third substance was found at Saldanha Bay on the const of Africa, imbedded in patches in the mass of guano. It is found in distinct crystals with numerous modifications, many of the planes possessing sufficient brilliancy to enable me to measure the angles by the reflecting goniometer. I have given the measurements of one crystal, from which it appears the primary form is the right rhombic prism of $57^{\circ} 30^{\prime}$ and $122^{\circ} 30^{\prime}$ : it has a cleavage parallel to plane $\mathrm{M} *$. Upon analysis $I$ find this substance to be composed of -

$$
\begin{array}{lll}
14 \cdot 30 & \text { parts of Ammonia. } & \text { Ames. } \\
17 \cdot 00 & \ldots & \text { Magnesia. } \\
30 \cdot 40 & \ldots & \text { Phosphoric acid. } \\
38 \cdot 10 & \ldots & \text { Water. } \\
\hline 99 \cdot 80 & &
\end{array}
$$

which is nearly equivalent to 1 atom ammonia, 1 atom magnesia, 1 atom phosphoric acid, 5 atoms water.

\section{Formula $\mathrm{NH}_{3}, \mathrm{MgO}, \mathrm{PO}_{5}+5 \mathrm{HO}$.}

$\mathrm{It}$ is therefore the ammonio-magnesian phosphate. The specific gravity is $1 \cdot 65$, hardness 2 ; it falls to powder before the blowpipe, giving off' water and ammonia. It occurs white, translucent, sometimes coloured brown by the guano; it readily dissolves in weak acids.

This substance is clearly derived from the guano; but being insoluble in water, it must have been held in solution by some of the organic acids of the guano, and deposited therefrom in large crystals, as they are found, but disseminated in patches only of the guano, in varions parts of the beds.

'This substance not having been found before in a native state, but hitherto only known as one of the artificial products of the laboratory, must be considered as a new mineral body; I therefore propose to give it the mineralogical name of Guanite, this name being derived from the circumstances and locality of its formation.

The source from which the first two substances, namely, the phosphate of ammonia and the bicarbonate of ammonia,

* See the angular measurements subjoined. 
are derived, is clearly the percolation of water through the guano beds dissolving out these salts, which running into lower situations may be detained in lagoons and hollows of rocks, where being subject to the high temperature of the climate they would be evaporated down, leaving these salts in the crystalline state described. As guano contains abundance of these two salts, it is possible there may exist considerable masses of them; should this be the case, it is evident that to the chemist in particular it would be of great interest as an additional source of these valuable salts.

The chance of finding any considerable quantity of guanite in the state of crystals is not great, but as it forms one of the ingredients of guano it is a substance of some importance. The application of it as a manure in combination with other ingredients is likely to be highly beneficial, it being a compound containing two important substances in an insoluble state, namely, ammonia and phosphoric acid; these may he taken up by plants only as they may be required, and not be liable to be dissolved out of the soil or evaporated like other ammoniacal salts.

The last substance which I shall describe was also found imbedded in the guano from Saldanha Bay; it consists of small globular particles composed of concentric laminæ slightly adhering together, of a yellowish white colour, containing in places portions of a similar nature, which on fracture have appearances of an organic structure like bone, but on examination by the microscope proved to be portions of shells resembling Nummulites. On analysis I found the substance to be composed of -
37.50 parts Carbonate of lime.
$32.50 \quad \ldots \quad$ Carbonate of magnesia.
12.00 ... Phosphate of lime.
$12 \cdot 00 \quad \ldots$ Water with a little ammonia and animal matter.
$3 \cdot 00 \quad \ldots \quad$ Sand.
$\frac{2 \cdot 50}{99^{\cdot 50}}$... Alkaline sulphates and chlorides.

There does not appear to be any great quantity of this substance. How it has been formed it is difficult to imagine; the composition is so very different either from that of bones or shells, particularly in regard to the large quantity of carbonate of magnesia which it contains. It is however probable that both bones and shells form the base of this substance, and that partial decomposition having taken place, the magnesia may have subsequently entered into combination with the carbonate and phosphate of lime. 


\section{Measurements of Guanite.}

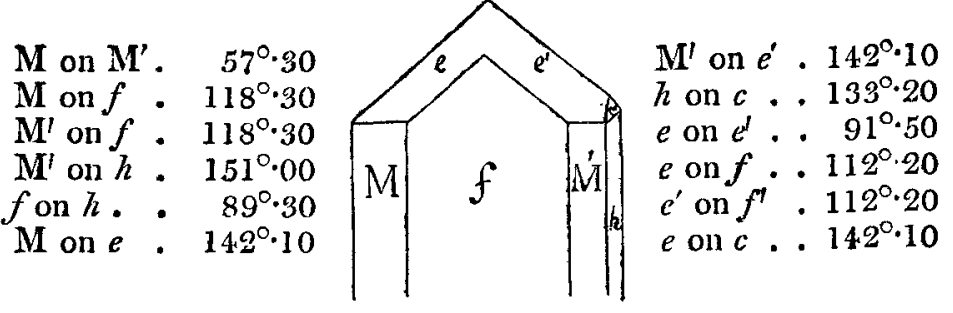

LXXXV. Notes on the Preparation of Alloxan. By William Gregory, M.D., F.R.S.E.*

$\mathrm{N}$ an interesting and able paper on alloxan and its derivatives, the first part of which appears in Liebig's $A m$. nalen for September 1845, Schlieper enters into minute details concerning the most advantageous method of preparing alloxan, and after describing the results which he obtained on repeating the process given by me, proposes a new method of his own, which be consider's in every way preferable, as yielding, with greater facility and certainty, a larger proportion of alloxan. Professor Liebiy in his Lectures (Lancet 184.5) also recommends Schlieper's method as the best in every respect.

I am still, notwithstanding, inclined to give a decided preference to my own process, when carefully performed, and that on the grounds of its superior simplicity, facility and productiveness. A brief comparison of the two methods, with their results, will enable the reader to judge for himself.

I must first of all, however, observe, that Scblieper, in repeating my process, has not obtained results so favourable as I had formerly announced; so that, in his hands, his own method has been the more productive. I formerly obtained from 100 parts of uric acid 90 of crystallized (hydrated) alloxan, perfectly pure, not reckoning the portion of alloxan remaining in the mother-liquids. Schlieper, on the other hand, from 15 ounces of uric acid, treated by my process, obtained, including the contents of the mother-liquids, 8 ounces hydrated alloxan, $1 \frac{3}{4}$ ounce alloxantine $\left(=2 \frac{1}{4}\right.$ ounces alloxan $)$, and $\frac{3}{4}$ onnce parabanic acid ; in all equivalent to about $11 \frac{1}{4}$ ounces of alloxan. This only amounts to 75 per cent.; whereas I obtained 90 per cent., exclusive of the mother-liquids, which I find on an average to yield fully one-tenth mose; in all, therefore, at least 100 per cent. I may here state that I have

- Coramanicated by the Chenical Suciety; having been read Decenter 15,1845 . 